\title{
Hotel Sales Decline and Opportunities For a Turnaround: The Case of a Selected Hotel Chain in Swaziland (2008 - 2010)
}

\author{
Farayi Phillip Kanokanga, ${ }^{1}$ Sebastian Vengesayi, ${ }^{2}$ Patricia Mumbengegwi, ${ }^{3}$ \\ Cloetilda Kazembe ${ }^{4}$, Pauline Karigambe ${ }^{5}$ \\ ${ }^{1,2,3,4,5}$ School of Hospitality and Tourism, Chinhoyi University of Technology, Zimbabwe
}

\begin{abstract}
The study sought to explore the causes of sales decline and possibilities of a turnaround at some selected hotel chain in Swaziland between July 2008 and December 2010. In this study 5 senior managers, 12 middle level managers, 5 junior managers and 2 ordinary employees were used as research subjects. Fifty per cent of them were male and 42 per cent female. The study sought to facilitate the organisation to appreciate and fix the causes of sales decline; the hotels' personnel to be better motivated, and hotel guests to enjoy improved customer care. The study showed that stiff competition was the main cause of sales decline. Economic hardships, and low personnel motivation also played a part. The study recommended that staff motivation be taken more seriously. The use of the world's best practices was recommended as well as further research on casino operations.
\end{abstract}

Keywords: competition, hotel, opportunities, sales decline, turnaround

\section{Introduction}

One South African Hotel Chain is the 50.6 percent controlling shareholder in the selected hotels in Swaziland and holds the management contract for the hotels and casino. The hotels are located at the heart of the country's main tourism and hospitality enclave. Together they employ two hundred and twenty employees. One of the units is a five- star facility with a casino while the other two are three-star.

\section{Literature Review}

There is a dearth of research on causes of sales decline in the hotel sector. This is despite that it is a crucial sector of the hospitality and tourism industry and many hotel firms continue to go under. The SH hotels belong in the tourism and hospitality industry. According to [1], the most widely accepted modern definition of tourism is that given by the World Tourism Organization (WTO). It defines tourism as: "The activities of persons travelling to and staying in places outside their usual environment for not more than one consecutive year for leisure, business or other purposes." According to [2], the word hospitality derives from hospice, the term for a medieval house of rest for travellers and pilgrims. Hospitality, then, not only includes hotels and restaurants but also other kinds of institutions that offer shelter, food, or both to people away from their homes. As observed by [3], hotel organizations fail to reach their full potential or fail altogether owing to a plethora of factors. These include lack of consistency, electing and retaining the right staff and an incorrect menu structure. Ineffective or nonexistent marketing, little understanding of business figures (statistics) as well as working on the business (not in it) as well as a poorly presented concept of branding contribute to the failure of hotel firms. Lack of integrated business systems, a structured business plan and an ineffective control of the point of sale (POS) system all negatively affect hotel sales.

\subsection{How to Improve Sales}

Reference [4] proposes these four ways:

- Acquire another company

- $\quad$ Find new customers to buy from you.

- Get existing clients to spend more at each visit.

- $\quad$ Get existing customers to visit more frequently and spend more.

\subsection{IT and Customer Satisfaction}

According to a study by Morley [5], the impact and importance of IT in the infrastructure of the hotel sector have had solid strategic implications for industry leaders. Increasing reliance on IT systems is the wave of the future and is expected to continue to alter operations significantly [6]. Both academic researchers and industry personnel have paid attention to the already substantial impacts IT has had and to the potential for even more dominant contributions to the hospitality and tourism industry. Implementation of IT systems has resulted 
in decreased costs, greater productivity and increased revenues in the lodging industry (Siguaw et al., 2000; Huo, 1998), improving customer service and business operations (Sweat and Hibbard, 1999; Barcheldor, 1999; Van Hoof et al., 1996). [7] Points out that the Hilton Hotel Corporation has led the way for IT in the hotel industry, with the implementation of a consistent IT system throughout all its properties. However, to maintain relevance, the IT needs to be upgraded and reviewed as necessary to suit environmental dynamics.

\subsection{Case Study: Fairmont Hotels and Resorts}

Reference [8] postulates that Fairmont Hotels and Resorts is a good example of a company that aims its marketing efforts towards its employees. Fairmont is the largest luxury hotel management company in North America-Canada and has achieved great success since it opened in 1914. The company now operates 77 hotels with about 30,000 rooms and employs 28,000 people. It believes that staff loyalty encourages customer loyalty. It has invested in internal marketing. Reference [9] observes that the company measures the success or failure of its internal marketing programs through employee turnover - currently running at about 20 percent, with the hotel industry averaging five or six times higher. Staff loyalty in turn encourages customer loyalty; repeat guests make up 60 percent of Fairmont's business.

Fairmont Hotels and Resorts utilize staff empowerment. Staff empowerment is defined by [9] as the act of giving employees the authority to identify and solve guest problems or complaints on the spot, and to make improvements in the work processes.

\subsection{Employees as Part of the Hotel Product}

Once Fairmont has attracted and recruited the right employees, as observed by [9], attention is focused on keeping them satisfied and motivated to impress the guests. Substantial discounts of up to 50 percent off food, beverages and hotel rates are offered as employee incentives to encourage them to use these products/ services, thus facilitating first - hand knowledge. Employees are part of the product, and encouraging them to be excited about Fairmont hotels and services will in turn make the customer more excited. Fairmont also has a number of recognition awards that are presented throughout the year. The strategy of building marketing strategy around employees is also supported by [10].

\subsection{Market Structure For Hotel Firms}

Reference [11] point out that the behaviour of the firm depends on the features of the market in which it sells its products and on its production costs. Hotels belong to the monopolistically competitive (MC) market. As the name indicates, monopolistic competition combines certain features of monopoly and perfect competition. This view is echoed by [12] who argue that it is a market situation between the extremes of perfect competition and monopoly and displays features of both. One major characteristic of monopolistic competition is product differentiation [11].

\subsection{Hotel Value Chain and Strategy}

In a hotel situation core activities include site development and construction ( by local owner), marketing and sales ( by brand, regional office, and property), service delivery and operations (that is, check - in check-out ), and in - room services at property level and by management company, service monitoring , and post - stay service enhancement [13]. Support activities allow the hotel to function and to provide the core activities. Examples of such activities include Human Resources, Maintenance, Information Technology, Accounting and Purchasing. It can be argued though that with hotel products and experiences, technology for example, may be so vital to a one customer, it is a core activity just as an accurate bill (accounting process). According to [14], the key is to list all the major activities of the firm that add value to the overall process and thus influence performance. This should be reflected in the firm's strategy.

\section{Research Methodology}

The research design was a descriptive survey. The target population consisted of all line managers including the Area General Manager, Marketing, Finance, Human Resource, Food and Beverage, Housekeeping, Front Office, Public Relations, Maintenance and Casino including assistants and supervisors as well as all staff above 25 years of age. A sample of 24 research subjects (respondents) was used comprising largely those in managerial positions since they were at the centre of sales management. Judgmental sampling was used because the researchers felt that managers were critical as they were at the heart of all sales operations and interfaced between lower level employees and senior management. The semi-structured self - administered questionnaire was used to collect responses from management and staff. The interview checklist was used to probe the managers since the number was manageable and there was need to ask follow-up questions. The instrument was developed to capture the main themes which were explored in the study including: the profile of the respondents, the level of motivation among the personnel, the level of competition, causes of sales decline 
and ways of improving sales. The staff of the smallest hotel was used to pre - test the questionnaire and thereafter they played no further role in the study. Descriptive statistics were used to analyse the data. Absolute and relative percentage frequencies were used to objectively establish research findings.

\section{Results and Discussion}

Thirty questionnaires were distributed and twenty four were returned giving a response rate of $80 \%$ which was quite high and appreciable.

\section{Research question A.1: Please indicate your gender.}

Table 1 Showing Gender Composition of Respondents

\begin{tabular}{||l||l||l||}
\hline \hline Gender & Frequency & $\%$ \\
\hline \hline Male & 14 & $\mathbf{5 8}$ \\
\hline Female & 10 & $\mathbf{4 2}$ \\
\hline Total & $\mathbf{2 4}$ & $\mathbf{1 0 0}$ \\
\hline
\end{tabular}

Table 1 shows that the majority, $58 \%$ of the respondents were males and $42 \%$ were females.

On a rating scale of $1-10$, (one being awful and ten being great), the 24 respondents' ratings were aggregated as follows:

\section{Research question A.2: Please assess the company on the following aspects:}

Table 2 Denoting Level of Job Satisfaction Among Personnel.

\begin{tabular}{|l|l|l|l|l|}
\hline Factor & $\begin{array}{l}\text { Possible } \\
\text { Respondents }\end{array}$ & $\begin{array}{l}\text { Possible Score } \\
(\mathbf{2 4 0} \text { points) }\end{array}$ & $\begin{array}{l}\text { Actual Score } \\
\text { (points) }\end{array}$ & \%Score \\
\hline Compensation to employees & 24 & 240 & 96 & 40 \\
\hline Opportunity for advancement & 24 & 240 & 168 & 70 \\
\hline Benefits & 24 & 240 & 88 & 37 \\
\hline Friendly work environment & 24 & 240 & 124 & 52 \\
\hline Training & 24 & 240 & 204 & 85 \\
\hline Performance evaluation & 24 & 240 & 155 & 65 \\
\hline Supervision & 24 & 240 & 190 & 79 \\
\hline Company Culture & 24 & 240 & 161 & 67 \\
\hline Job Security & 24 & 240 & 126 & 55 \\
\hline Flexibility in performing job & 24 & 240 & 128 & 53 \\
\hline Overall job satisfaction & 24 & 53 & $\mathbf{5 3}$ \\
\hline
\end{tabular}

As indicated in Table 2, the 24 respondents awarded training an aggregate score of 85\%; scoring 204 points out of 240 points possible. They awarded supervision an aggregate score of 79\%; scoring 190 points out of 240 points possible. The results showed that the company was doing quite well as regards training and supervision of managers and staff. However, the respondents awarded company benefits an aggregate score of $37 \%$, scoring only 88 points out of 240 and compensation to employee was awarded $40 \%$; scoring only 96 points out of a maximum possible of 240 .

According to Adams' Equity theory of motivation cited by [15], employees are constantly comparing their inputs (commitment, effort and others) with the outputs (salary, benefits, promotion and others.) Any disequilibrium identified is corrected accordingly - either by putting more effort or reducing it. This supports the argument by [8] that customer satisfaction was difficult to achieve in the absence of employee satisfaction. Thirty eight percent of respondents said the current situation was de-motivating and morale was at low ebb. Forty six percent believed that there was a need for the company to improve remuneration.

\subsection{Training}

Most of the respondents indicated that they were well trained and required no additional training. While the majority of respondents $-85 \%$ said they were well trained, the general view was also that SH did not remunerate fairly and satisfactorily. Staff motivation was at a low ebb. This diminishes the impact of training.

\subsection{Rivalry}

Sixty seven percent of the respondents felt that stiff competition was the chief cause of sales decline at SH hotels. As pointed out by [8], the opening of the Borgata Hotel, casino, and Spa in Atlantic City (USA) was a typical example of overwhelming the competition. This case closely resembles that of the opening of one big competitor with casino in Swaziland in 2009.The above finding suggested that SH had to craft strategies to overwhelm the competition if they were to become the hotel of choice for many customers. 


\section{Research question A.3: Please rate the contribution of each factor to sales decline: \\ Table 3 Showing Ranking of the Causes of Sales Decline}

\begin{tabular}{|l||l||l||l||}
\hline \multicolumn{1}{|l||}{ Factor } & Possible & Actual & \% \\
\hline \hline Stiff competition & 24 & 16 & $\mathbf{6 7}$ \\
\hline Economic hardships & 24 & 15 & $\mathbf{6 3}$ \\
\hline High prices & 24 & 12 & $\mathbf{5 0}$ \\
\hline Stock shortages & 24 & 8 & $\mathbf{3 3}$ \\
\hline Seasonal variations & 24 & 8 & $\mathbf{3 3}$ \\
\hline Low staff motivation & 24 & 7 & $\mathbf{2 9}$ \\
\hline Outdated technology & 24 & 5 & $\mathbf{2 1}$ \\
\hline Poor customer care & 24 & 4 & $\mathbf{1 7}$ \\
\hline Inferior products & 24 & 4 & $\mathbf{1 7}$ \\
\hline Poor after - sales - service & 24 & 4 & $\mathbf{1 7}$ \\
\hline Rigid payment methods & 24 & 1 & $\mathbf{4}$ \\
\hline Lack of advertising & 24 & 0 & $\mathbf{0}$ \\
\hline
\end{tabular}

Table 3 above shows that economic hardships (63\%) significantly impacted sales volumes while $50 \%$ felt prices were higher than those of major competitors. As indicated in literature, differentiation and the presence of many firms are key features of monopolistic competition. These features should be carefully studied and a winning business strategy crafted.Stock shortages and seasonal variations also contributed to sales decline.

\subsection{SalesTrend Turnaround}

The study has revealed that $\mathrm{SH}$ hotels have to be more accommodative with their pricing. This could have been prompted by the presence of a new competitor with a modern casino, $5 \mathrm{~km}$ away, charging room rates almost half those of SH hotels in some cases. Some (21\%) felt the outdated technology needed replacement.

\section{Conclusion}

The study showed that stiff competition was the main cause of sales decline. Economic hardships, high prices, stock shortages, seasonal variations and low motivation among the personnel were contributory factors. The absence of job security created a feeling of apprehension and removed the sense of belonging among the personnel. The world's best practices in the hotel sector were recommended. It was also recommended that further research be conducted to solicit for customer views on customer satisfaction and to conduct a detailed study on casino operations of SH hotels. Competitive forces are becoming so strong in the hotel industry that being good is no longer good enough. Also, hotel operators often fail to identify their competitors correctly. According to the marketing concept, for a hotel business to be successful, it must satisfy the needs and wants of consumers better than its competitors. Marketers should do more than simply adapting to the needs of target customers. In this regard, the SH hotels needed to gain strategic advantage by strongly positioning their products in the minds of consumers. Sales decline may lead to hotel failure. Hotel failures lead to loss of both jobs and invested capital. Hotel entrepreneurs and their investors could also face economic hardships owing to hotel failure. This implies that hotel failure has a significant effect on the economy.

\section{References}

[1] J. Beech and S. Chadwick, The business of tourism management, $3^{\text {rd }}$ edition (Prentice - Hall, Harlow, 2006)

[2] C.W Barrows and T. Powers, Introduction to management in the hospitality industry, $9^{\text {th }}$ Edition(John Wiley and Sons, New Jersey, 2009)

[3] J. Lonergan, Why do hospitality business fail?Retrieved from http://www.cuisine scene hospitality solutions.com

[4] Ainsworth L. (2008). There are only four ways to increase a company's revenue. Retrieved from: <http://www.ezinearticles.com

[5] C.L. Morley, (Managing Tourism Firms: Economics and Management of Tourism,(Edward Elgar Publishing, Inc, Massachussets, 2007)

[6] M. Sigala, The information and communication technologies productivity impact on the UK hotel sector, International Journal of Operations \& Production Management, Vol. 23 Issue 10,2003, pp. 1224-1245;

[7] M.L. Schwartz, Impact of IT on hotel industry and Hilton Hotel Corporation, a research paper. 2007

[8] D.Bowie and F.Buttle, Hospitality marketing - an introduction, (Buttersworth - Heinemann, Oxford, 2004).

[9] S. Hudson, Tourism and hospitality marketing - a global perspective, (Sage Publications, London, 2008)

[10] T. McComb, The implementation of the suggestive selling training programfor the employees of the XYZ Resort and Casino, msc diss., he Graduate College, University of Wisconsin - Stout, Menomonie, 1999.

[11] P.L Mohr and C.Fourie \& Associates, Economics for South African students, $3^{\text {rd }}$ Edition, (New Schaik Publishers, Pretoria, 2004).

[12] J.Sloman and A. Wride, Economics $7^{\text {th }}$ Edition, (Prentice Hall, Essex, 2009)

[13] C.AEnz, Hospitality strategic management - concepts and cases $-2^{\text {nd }}$ Edition - (John Wiley and Sons Inc. New Jersey, 2010).

[14] W.D. Perrault and E.J. McCarthy, Essentials of marketing 10 $0^{\text {th }}$ edition, A Global Managerial Approach,(McGraw - Hill, New York, 2006)

[15] C.R. Milton, Human Behaviour in organizations: three levels of behavior, (Prentice - Hall,Engelwood Cliffs, 1981).

[16] P. J.Kotler and J T. Bowen, Marketing for hospitality and tourism, $4^{\text {th }}$ edition,(Prentice - Hall, New Jersey, 2006). 